\title{
Bioelectricity Generation and Treatment of Sugar Mill Effluent Using a Microbial Fuel Cell
}

\author{
Ravinder Kumar, Lakhveer Singh, and A.W. Zularisam
}

\begin{abstract}
Microbial fuel cells are (MFCs) fascinating bioelectrochemical devices that use living catalysts to produce electric energy from organic matter present naturally in the environment or in waste. In this study, sugar mill effluent (SME) was used as the anodic substrate in a double chambered MFC for an application of electricity generation. The maximum power density, $140 \mathrm{~mW} / \mathrm{m}^{2}$ was achieved with $50 \%$ concentration of SME. Maximum chemical oxygen demand (COD) removal obtained was $56 \%$ when $50 \%$ concentration of SME was used as the anodic substrate. These results demonstrated that SME is a suitable substrate in a MFC for bioelectricity production and its treatment.
\end{abstract}

Index Terms-Microbial fuel cell, sugar mill effluent, bioelectricity.

\section{INTRODUCTION}

Microbial fuel cells (MFCs) are bioelectrochemical devices, a fascinating emerging technology used for the generation of electric current from different complex organic and inorganic sources using living microorganisms as biocatalysts [1]. A MFC generally consists of two chambers, an anode (anaerobic chamber) and a cathode (aerobic chamber). The anode and the cathode are interconnected by a proton exchange membrane (generally made up of Nafion or Ultrix). The microorganisms at the anode oxidize the organic compounds to carbon dioxide, electrons and protons. Electrons can be transferred to the anode by electron mediators or shuttles and via electrically conductive filaments, known as nanowires [2]. Chemical mediators (e.g. neutral red) can also be added to the system to allow electricity production by bacteria which otherwise unable to use the electrode [3]. Electrons transferred to the anode pass through a resistor or other type of electrical device to the cathode. The cathode may be exposed to the air or submerged in aerobic water. Protons released migrate to the cathode through a proton exchange membrane, where they combine with electrons and oxygen to form water [4]. Besides electricity generation, other applications of MFCs are bioremediation, sensors and powering electronic monitoring devices [5].

Interestingly, MFCs are also able to treat wastewater and produce electricity simultaneously. The substrate is a pivotal factor along with electrode material, membrane material, and reactor design which influences the performance of

Manuscript received April 28, 2015; revised June 25, 2015. This work was supported by the Universiti Malaysia Pahang Research Scheme (grant no. RDU-140379).

The authors are with the Faculty of Engineering Technology, Universiti Malaysia Pahang, Lebuhraya Tun Razak Gambang, Kuantan, Pahang 26300, Malaysia (e-mail: raviump@gmail.com, lucki.chem09@gmail.com, zularisam@ump.edu.my).
MFC [6]. Substrates such as swine wastewater, starch processing wastewater, brewery wastewater, and domestic wastewater resulted in low-power density whereas simple substrates such as glucose, acetate has been intensely studied which showed high-power density [7]. In sugar mill industry, a large amount of water is consumed during saccharification process which results in huge wastewater referred as SME. SME has a high content of the organic material and subsequently high biochemical oxygen demand (BOD), particularly because of the presence of sugars and organic material in the beet or cane. Earlier reported typical levels of biochemical oxygen demand (BOD) are 4000$7000 \mathrm{mg} / \mathrm{L}$ in untreated SME while chemical oxygen demand (COD) is up to $10,000 \mathrm{mg} / \mathrm{L}$ and the total suspended solids are up to $5000 \mathrm{mg} / \mathrm{L}$. In addition to the sugars and organic materials, SME also contains crop pests, pesticide residues, and pathogens [8]. Electricity production by MFCs has been reported in the literature using carbohydrate-rich wastes such as food processing wastewater, starch processing wastewater and chocolatebased wastewater [9]. In this study, sugar mill wastewater was used as the substrate to produce electricity and for wastewater treatment.

\section{MATERIALS AND METHODS}

\section{A. Sample Collection and Characterization}

SME was collected from Malayan Sugar Manufacturing Company BHD, Jalan Sultan Ismail, Kuala Lumpur, Malaysia and kept in a refrigerator at $4^{0} \mathrm{C}$ before to use. Standard SME (100\% waste concentration) was diluted with distilled water and $\mathrm{pH}$ was adjusted in the range from 7 to 7.2 for the adaptation of microbial growth, further, $50 \%$ SME was taken throughout the study. Other characteristics of SME (50\%) are given in Table I.

\section{B. MFC Configuration and Operation}

A double chamber MFC used for the study was constructed of the glass material (borosilicate) with a working volume of $500 \mathrm{~mL}$ purchased from Shangai Sunny Scientific, China. An equal size of polyacrylonitrile carbon felt $(\mathrm{PACF})(4.5 \times 0.5 \times 5)$ was used as the electrode in both chambers of MFC. The anode and cathode chambers were separated by a Nafion 117 membrane (Dupont Co., USA), was drenched overnight in dilute HCL followed by washing with DI water 4-5 times prior to use. Prior to use PACF in MFC, it was washed 4-5 times with water to remove impurities. SME (50\%) was loaded in the anode chamber and was inoculated with anaerobic sludge under $\mathrm{N}_{2}$ atmosphere. $\mathrm{KmNO}_{4}$ solution was used as catholyte and its concentration was kept constant throughout the experiment. 
The anode and cathode electrodes were connected by using copper wires with a resistor to form a circuit. The MFC was operated at the ambient temperature from 25 to $28^{\circ} \mathrm{C}$.

\section{Measurement and Analysis}

A digital multimeter with a data logger (Fluke 289) was used to measure voltage and current across an external $1000 \Omega$ resistor. Power density (PV, Watts per cubic meter) normalized by volume and power density normalized by surface area (PA, Watts per square meter) were measured and calculated using the following equations:

$$
\begin{gathered}
P=V I \\
P_{A N}=V^{2} / A_{A N} R \\
P_{v}=V^{2} / v R
\end{gathered}
$$

where $A=$ area of anode electrode (square meter), $P=$ power (Watts), $V=$ the potential (volts), $v=$ working volume of anode (cubic meter), $R=$ external resistance (ohm) and $I$ $=$ current (ampere). The Coulombic efficiency of the system was calculated by integrating the measured current relative to the maximum current possible based on the observed COD removal. Further, the wastewater characteristics such as chemical oxygen demand (COD), total solids, total suspended solids, ammoniacal nitrogen, nitrate nitrogen, and total dissolved solids were analyzed for SME by standard methods [9]. Moreover, SME from the anode was tested for COD periodically for every $24 \mathrm{~h}$. The COD of SME was determined using a COD cell test kit (0-1,500$\mathrm{mg} / \mathrm{L}$ range; Hach, USA) and measured using a COD reader (Hach DRB 200, USA). The COD removal efficiency $(\eta)$ was calculated using the equation; $\eta=\mathrm{COD} 0-\mathrm{COD} / \mathrm{COD} 0$, where COD0 is the initial COD of SME in anode chamber and CODt is COD of SME in anode chamber at a particular time.

\section{RESUlTS AND DISCUSSION}

\section{A. Power Generation}

The MFC was operated with $50 \%$ of SME for simultaneous power generation and wastewater treatment; the microorganisms needed were already present in SME. After a complete a cycle of replacing the wastewater over $118 \mathrm{~h}$, maximum voltage $318 \mathrm{mV}$ was obtained $(1000 \Omega)$, producing a maximum power density $140 \mathrm{~mW} / \mathrm{m}^{2}(1000 \Omega$, $50 \mathrm{~mA} / \mathrm{m}^{2}$ ) with $50 \%$ of SME, shown in Fig. 1. The initial power generation was lower due to the low catalytic activity of microorganisms present in the wastewater. Thereafter the power generation increased because of higher biological activity. Power generation vs. time from 50\% of SME is presented in Fig. 2. It reveals that power generation in the batch mode included the ascending phase followed by the stationary phase. As the initial COD of the SME was high, more substrates were available for the microorganisms to oxidize. However, some of the substrates were converted into fermentation products; subsequently most of the electrons were not available for the power generation. The lower power density obtained could be due to the higher internal resistance caused by the presence of a membrane, the longer distance between the anode and cathode electrodes and the ohmic loss [10].

TABLE I: PHYSIOCHEMICAL PROPERTIES OF 50\% SUGAR MILl EFFLUENT

\begin{tabular}{lc}
\hline Parameters & Characteristic value \\
\hline Color & Blackish grey \\
$\mathrm{pH}$ & $7-7.2$ \\
Chemical oxygen demand (COD) & 7210 \\
Biological oxygen demand (BOD) & 2850 \\
Alkalinity & 550 \\
Dissolved solids & 1875 \\
Suspended solids & 318 \\
Ammoniacal nitrogen & 16 \\
Nitrate nitrogen & 98 \\
\hline
\end{tabular}

Note: All values are in mg/l except $\mathrm{pH}$ and color.

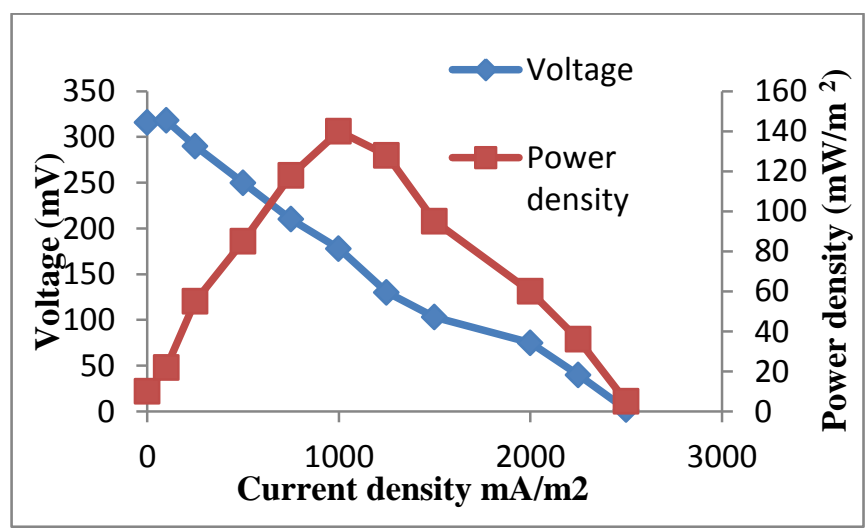

Fig. 1. Power density and voltage as a function of current density obtained using external resistors of $10 \Omega$ to $1000 \Omega$.

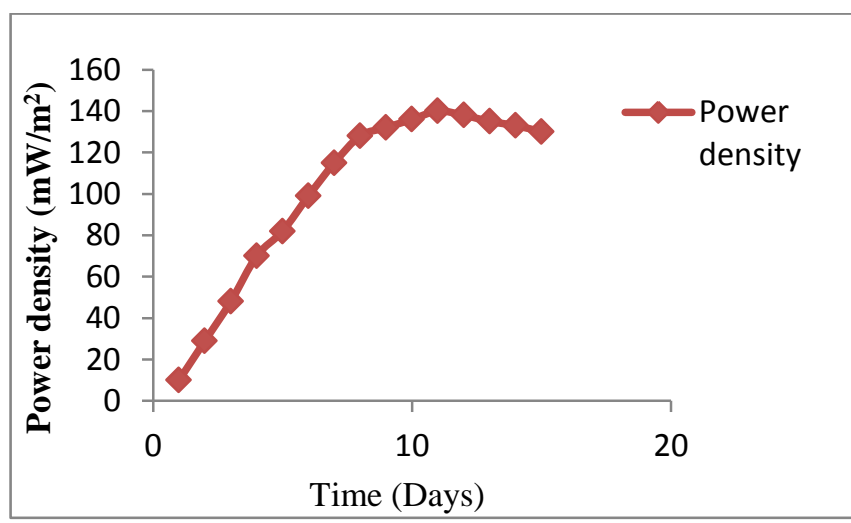

Fig. 2. Power density generation (maximum power density has been taken of each day after measuring every 30 minutes).

Clostridium sp. and Thiobacillus ferrooxidans have been reported predominantly in SME and the other unknown diverse bacterial populations may also exist in SME. The microorganisms present in SME anaerobically metabolize the complex carbohydrates into simple molecules. The existence of cytochromes on the outer membrane of 
Clostridium sp. has already been reported [11]. The electrons produced during the oxidation of complex molecules in the anode chamber are directly transferred to the electrode through the cytochromes. Fermentative bacteria are required to metabolize the complex organic materials of SME into fermentation products to generate bioelectricity. The lack of electrochemically active bacteria could also be the reason for low power density due to the incomplete utilization of SME and consequently.

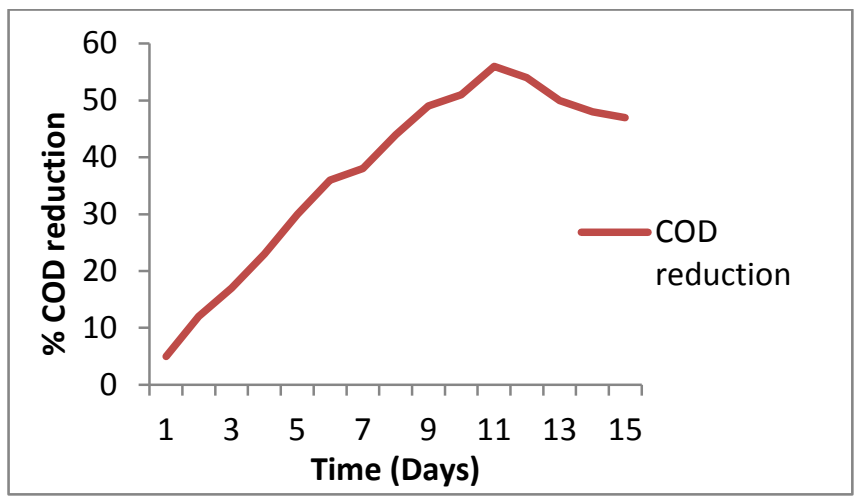

Fig. 3. Effect of initial COD on coulombic efficiency and power density.

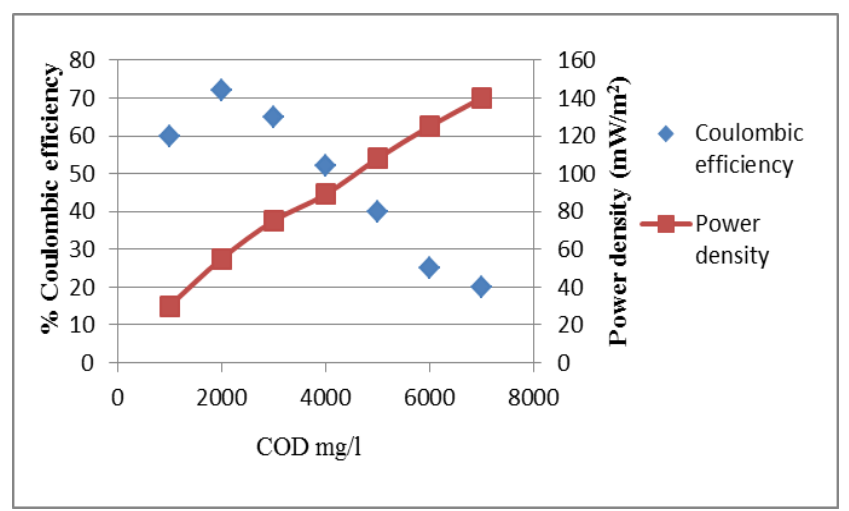

Fig. 4. \% COD removal efficiency of MFC using 50\% sugar mill effluent.

\section{B. Efficiency of MFC and Treatment of SME}

SME treatment and efficiency of the MFC with SME was evaluated by comparing before and after treatment values of wastewater parameters. MFC was operated for 15 days and wastewater parameters were examined on each operating day. On the initial days, MFC didn't show much efficiency and treatment but showed maximum efficiency and treatment between $10^{\text {th }}$ and $12^{\text {th }}$ day. In this study, about $56 \%$ of maximum COD removal was achieved from $50 \%$ of SME, described in Fig. 4. Sugar industrial effluent was treated earlier with different techniques which showed better results; more than $90 \%$ COD removal was obtained when beet sugar wastewater was treated with up-flow anaerobic fixed bed (UAFB) bioprocess technology [12]. Also, about $86 \%$ COD was achieved when simulated beet sugar factory wastewater was treated electrochemically [13]. However, maximum BOD removal and dissolved solids removal determined in this study were $54 \%$ and $60 \%$ respectively.

\section{Effect of Initial COD on Coulombic Efficiency and Power Density}

The coulombic efficiency (CE) was measured and related with initial COD, our results showed that CE decreased with the increase in initial COD and power density increased with increase in initial COD. The variation of coulombic efficiency and power density with initial COD is presented in Fig. 3. The coulombic efficiency of wastewater depends on the complexity of different substrates present in wastewater. MFCs fed with complex wastewater showed low coulombic efficiency in the earlier studies [14]. A maximum $72 \% \mathrm{CE}$ was achieved in the study which was quite appreciable. Cell growth can decrease the coulombic efficiency due to the diversion of electrons into biomass. Power density decreases with a decrease in initial COD. High power densities were achieved with SME of high COD values [15]. Maximum power density $140 \mathrm{~mW} / \mathrm{m}^{2}$ was measured successfully in the operation of using 50\% SME.

\section{CONCLUSION}

In this study, an MFC was operated using SME for bioelectricity production and its treatment. Polyacrylonitrile carbon felt was used as the electrode material in both chambers of the MFC. The cell was operated for 15 days in batch-fed mode. The maximum power density $140 \mathrm{~mW} / \mathrm{m}^{2}$ was successfully achieved and maximum $56 \%$ reduction in COD was measured using 50\% SME as a substrate.

\section{ACKNOWLEDGMENT}

The authors are thankful to the Universiti Malaysia Pahang Research Scheme (grant no. RDU-140379) for financial support.

\section{REFERENCES}

[1] B. E. Logan and K. Rabaey, "Conversion of wastes into bioelectricity and chemicals by using microbial electrochemical technologies," Science, vol. 337, pp. 686-690, August 2012.

[2] J. W. Voordeckers, B. C. Kim, M. Izallalen, and D. R. Lovley, "Role of Geobacter sulfurreducens outer surface c-type cytochromes in reduction of soil humic acid and anthraquinone-2, 6- disulfonate," Applied and Environmental Microbiology, vol. 76, pp. 2371-2375, April 2010.

[3] R. Kumar, L. Singh, Z. A. Wahid, and M. F. M. Din, "Exoelectrogens in microbial fuel cells toward bioelectricity generation: A review," International Journal of Energy Research, vol. 39, pp. 1048-1067, June 2015.

[4] D. H. Park and J. G. Zeikus, "Utilization of electrically reduced neutral red by Actinobacillus succinogenes: Physiological function of neutral red in membrane-driven fumarate reduction and energy conservation," Journal of Bacteriology, vol. 181, pp. 2403-2410, April 1999.

[5] S. K. Chaudhuri and D. R. Lovley, "Electricity generation by direct oxidation of glucose in mediatorless microbial fuel cells," Nature Biotechnology, vol. 21, pp. 1229-1232, September 2003.

[6] H. Ren, H. S. Lee, and J. Chae, "Miniaturizing microbial fuel cells for potential portable power sources: Promises and challenges," Microfluid Nanofluid, vol. 13, pp. 353-381, May 2012.

[7] K. Rabaey, N. Boon, S. D. Siciliano, M. Verhaege, and W. Verstraete, "Biofuel cells select for microbial consortia that self-mediate electron transfer," Applied and Environmental Microbiology, vol. 70, pp. 5373-5382, September 2004.

[8] K. J. Chae, M. J. Choi, J. W. Lee, K. Y. Kim, and I. S. Kim, "Effect of different substrates on the performance, bacterial diversity, and bacterial viability in microbial fuel cells," Bioresource Technology, vol. 100 , pp. 3518-3525, July 2009.

[9] J. Lee et al., "Use of acetate for enrichment of electrochemically active microorganisms and their $16 \mathrm{~S}$ rDNA analyses," FEMS Microbiology Letters, vol. 223, pp. 185-191, June 2003.

[10] A. Perendeci and D. Sural, "A review of wastewater pollution and treatment strategies for beet sugar factories in Turkey," International Sugar Journal, vol. 106, pp. 437-442, January 2004. 
[11] S. E. Oh and B. E. Logan, "Hydrogen and electricity production from a food processing wastewater using fermentation and microbial fuel cell technologies," Water Research, vol. 39, pp. 4673-4682, November 2005.

[12] S. A. Patil, V. P. Surakasi, S. Koul, S. Ijmulwar, A. Vivek, Y. S. Shouche, and B. P. Kapadnis, "Electricity generation using chocolate industry wastewater and its treatment in activated sludge based microbial fuel cell and analysis of developed microbial community in the anode chamber," Bioresoure Technology, vol. 100, pp. 51325139, November 2009.

[13] N. Lu, S. G. Zhou, L. Zhuang, J. T. Zhang, and J. R. Ni, "Electricity generation from starch processing wastewater using microbial fuel cell technology," Biochemical Engineering Journal, vol. 43, pp. 246251, March 2009.

[14] D. E. Andrew, S. C. Lenore, and E. G. Arnold, Standard Methods for the Examination of Water and Wastewater, 19th Ed. Washington, DC, APHA, AWWA, 1995

[15] B. Min, J. R. Kim, S. E. Oh, J. M. Regan, and B. E. Logan, "Electricity generation from swine wastewater using microbial fuel cells," Water Research, vol. 39, pp. 4961-4968, December 2005.

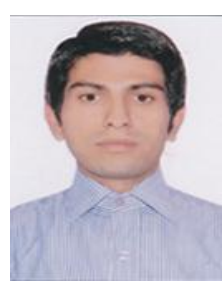

Ravinder Kumar was born in Himachal Pradesh, India on July 14, 1989. He finished his bachelor degree in life sciences from Himachal Pradesh University, Shimla in 2009. Further, he received a master degree in biotechnology from CCS University Meerut in 2011 and currently is a Ph.D. student in Universiti Malaysia Pahang working on microbial fuel cells.

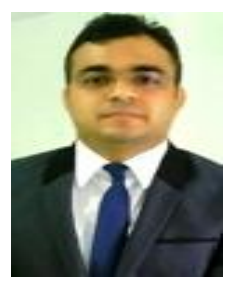

Lakhveer Singh is a senior lecturer in renewable energy and environmental engineering at the Faculty of Engineering Technology, Universiti Malaysia of Pahang. He received his B.Sc. and M.Sc. degrees in chemistry from Himachal Pradesh Universiti Shimla and Punjab Universiti Chandigarh, India, in 2007 and 2009, respectively, and received his Ph.D. degree in industrial chemistry from Universiti Malaysia Pahang (UMP) 2013. He has teaching, research and industries experiences with universities and industries in India. $\mathrm{He}$ is currently a senior lecturer at the Faculty of Engineering Technology, Universiti Malaysia of Pahang. His main areas of interest are bioenergy production, bioreactors development, wastewater treatment, MFC and green technology. In addition to research activities, he teaches undergraduate courses and guides doctoral students at Universiti Malaysia Pahang. He has a number of international publications. He also holds two patent filing application for his research. He is a reviewer of Elsevier, Wiley and springer International Journals. Presently he is the editor of Advance in Chemical and Biological Engineering Journal and a guest editor for International Journal of Energy Engineering. He is a senior member of Waste Recovery Research Group (UMP and UTM) Malaysia.

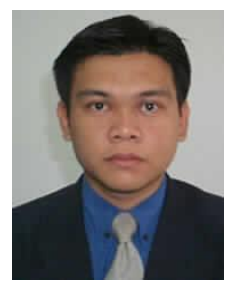

Zularisam Ab Wahid is a professor at the Faculty of Civil Engineering \& Earth Resources, Universiti Malaysia of Pahang. He started his career in industry in 1997 and worked with Petronas Carigali (M) Sdn Bhd before taking up an academic position at the Faculty of Chemical Engineering in 2002. He is currently the dean of the Faculty of Engineering Technology, Universiti Malaysia Pahang. Prof. Zularisam has been involved in research in the areas of environmental engineering, membrane fabrication and separation processes for several years at UMP and he is particularly known for his pioneering work in natural organic matter (NOM) removal for high quality drinking water production and recycling of wastewater. He has produced several commercial potential research products and holds numerous patent files such as BIOMEM, HyFE, MEMRAIN and SMBR. He also holds several US patent filling applications such as a system to produce hydrogen gas fuel (No: 12/765,117), a sustainable technology for treatment of batik waste effluent (No: 12/769,667) and a novel bio-membrane for drinking water filtration (No: 12/755,560). He was also a recipient of a British Special Award Grand Final Double Gold Industrial 2010 and a Gold medal winner at British Innovation \& Technology Show (BIS) London UK, a Gold winner at International Invention Show (INOVA) Zagreb, Croatia 2011 and a Gold winner at Innovation Technology Expo, K. Lumpur Malaysia 2010. Presently he is the editor of International Journal of Civil Engineering \& Geo-environmental, a life member of the Board of Engineer Malaysia (BEM), a member of European Desalination Society (EDS), the editor in chief for International Journal of Engineering Technology \& Sciences and peer reviewer of several well established journals. 